\title{
Refugees from South Asian Islamic States at the footsteps of Global North: Reading Moshin Hamid's Exit West as an Anticipation of Postnational Future
}

\author{
Minakshi Paul \\ Assistant Professor of English, Kandra Radhakanta Kundu Mahavidyalaya. \\ Email: mp951204@gmail.com
}

\begin{abstract}
One of the essential aspects which have been perpetually constituting and reconstituting the tumultuous geopolitical space of South Asia is its interface with the Global North. An inherent element of this interface materializes in terms of the rapidly escalating proportion of the displaced population from the Islamic South Asian and Central Asian countries afflicted with intense political tensions seeking shelter in the Global North regenerating the ground for the imperialist exclusionary politics in a newer manifestation. Considering the tensional position of the Islamic communities in global politics, British-Pakistani writer Moshin Hamid's novel Exit West (2017) provides a platform for exploring the plight of the refugees from Islamic states of South Asia in the fortress regime of Global North who are denied being assimilated either in their home state in Global South or in the host countries of the Global North thus problematizing their political status. Corroborating Giorgio Agamben's dismissal of national borders, Hamid deploys the trope of magical doors in his novel that instantaneously delivers the protagonists to different nations rendering the geopolitical borders meaningless. As the concerned conference's aspires to obviate the thick smog of western critical theories which fail to address the local issues and local cultural experience, the present paper in this context examines the novel as an aesthetic and poetical account of the hostility and resentment of the indigenous population and assimilated citizenry towards the refugees, the primal loss of their psychic experience of 'home' challenging the 'ethnonationalism' and the right wing populism of the western nations invoking the readers to acknowledge the truth of 'Postnationalism'. This paper thus attempts to diagnose the methods of negotiating the tensional correspondence between Global North and Global South on account of these refugees with contested political and social identities imploring the readers to reexamine the gaps in the complacent, coherent identity of South Asia as a geopolitical unit.
\end{abstract}

Keywords: South Asia, Refugee, Postnationalism, citizenship, Global North

This Open Access article is published under a Creative Commons Attribution Non-Commercial 4.0 International License (http://creativecommons.org/licenses/by-nc/4.0/), which permits non-commercial re-use, distribution, and reproduction in any medium, provided the original work is properly cited. For citation use the DOI. For commercial re-use, please contact editor@rupkatha.com. 


\section{Introduction}

South Asian identity as a geopolitical unit primarily draws its sense of consolidation and political authority from the ideology of Nation-states that rescued its honour and self-confidence after most of these countries were declared independent of imperial rule. Homi Bhabha in his The Location of Culture (2004) emphasized the significance of the "repetition and pulsation of the national sign"(211) to perpetuate its political consolidation in the international forum and the frequent reaffirmation of the ideology of Nation-states. emphasized These leads to the emergence of the significance of the geopolitical borders that sanction and ensure the individuality of these political units making them immune to any kind of political, cultural, or ethnic adulteration. Gellner defined nationalism early in his Nations and Nationalism as "a theory of political legitimacy, which requires that ethnic boundaries should not cut across political ones, and, in particular, those ethnic boundaries within a given state . . should not separate the powerholders from the rest" (1). But this global configuration with their presupposed complacency of political identities is disturbed [fascilitated] by the emergent issue of refugees and asylum Seekers.

Giorgio Agamben in his 1995 article "we Refugees" argues that the concept of the refugee not only 'calls into question the principles of the nation-state' but also 'helps clear the field for a [. . .] renewal of categories' (Agamben, 1995, p. 117). A somewhat similar view is reiterated by Navin Murshid in his book The Politics of Refugees (2014) in South Asia opined that how states have manipulated the refugee identity and resistance to promote the ideal of Nation-state. thereby creating a protracted Refugee crisis.

One of the primary entities blamed for problematizing the well-defined borders and segregation of the two halves of the world are the Muslim asylum seekers from either the south Asian or central Asian countries who are denied being acknowledged by and assimilated in neither the home countries nor in the host countries. Edward Said in his "Introduction to the Vintage Edition" of Covering Islam: How the Media and the Experts Determine How We See the Rest of the World (1997), observes that "malicious generalizations about Islam have become the last acceptable form of denigration of foreign culture in the west"(qtd in Hossain 2) In Wadok's (2008) terms it is the "ethnonationalist ideology" and the "politics of fear" (p.2) that generates the alienation of the refugees. The 9/11 and London bombings have increased the moral panic about Muslims perceived as 'hard to integrate' and a threat to western democracies. This magnifying number of asylum seekers thus ruptures the socio-political cartography persuading the readers to ponder upon what Benedict Anderson would have called "the anomalies of Nation".

Pakistani British novelist Moshin Hamid in his novel Exit West (2017) celebrates this rupture as an embarkment towards the postnational future emblematized by the magic doors in his novels that transports the refugees instantaneously across the borders. Meditating upon these magical borders Michael perfect has commented on the novel "e. As much as the doors in Exit West (2017) 
function as a comment on the refugee crisis of the novel's contemporary moment (something that perhaps seemed unthinkable until it happened), they also serve as a means of imagining a post-national future (something that may currently seem unthinkable, but which Hamid's novel suggests is possible, even likely)"(2)

Moshin Hamid is a significant name who made his presence established in the International literary space with his earlier three novels namely, Moth Smoke (2000), The Reluctant Fundamentalist (2007), and How to Get Filthy Rich in Rising Asia (2013). His fourth novel Exit West (2017) garnered much attention on account of the congruency of the fictive depiction of the raging issue of the European Refugee Crisis with the urgency and the relevance of the issue in the international forum. Honoured with several accolades New York Times Best Book of the Year, LA Times Book Prize for fiction, and shortlisted for the Man Booker Prize and the National Book Critics Circle Award. The novel has already made its pivotal mark in Refugee literature.

Exit West (2017) tries to track the journey of two lovers Saeed and Nadia who had to flee from their unnamed country in some South Asian Muslim state which was inflicted with civil war. Escorted by secret agents they are transported to the countries of the global north through the magic doors first to the Greek Island of Mykonos followed by metropolitan London and lastly to the new city of Marin, on the Pacific Ocean, close to San Francisco. The anonymity of the war-torn country to which the lovers originally belonged has been an issue of an enigma as well as a contest among the critics. Most of them like Lionel Shiver and others identified this unnamed city with either Aleppo or Mosul. When asked by The Hindu on the anonymity of the war-torn country in the novel, Hamid replied "My job is to include space for the reader to create." (Ram, 2017). In one of his interviews, Hamid himself admitted "I wrote it thinking of Lahore, modeling it after the city of Lahore, where I live". (Frostrup \& Hamid, 2017)

\section{What is a PostNational imagination?}

Postnational Imagination as a particular theoretical entity has been generated to combat the limitations that the strict affiliation with the ideology of the Nation-States engendered. Globalization mobilized the process of the flexibilization of the hitherto confined social, economic, and political spaces and assisted in their extension across vast global expanses. As a radical theoretical entity proposed by the critical thinkers, Postnational Imagination acknowledges and addresses a new subjectivity in man repeatedly fraught by the disruptive changes in the dynamic space of the contemporary neoliberal world. Within this new dynamic paradigm of "identity, including the ways in which humanity itself is constructed, come under scrutiny, the nation as a frame of social identification and organization cannot escape questioning." (Spencer, 2019 p.4)

Driven by a postnational imagination, Hamid in his novel not only endeavours to decipher ways to negotiate nationality's loss of prominence in the global world but also hints towards the already 
materialized forms of mass migration, global culture, and transnational economics. Weaponizing the entity of Postnational Imagination enables Hamid to thwart the strict adherence to the national identity and transform the refugee into what 'a persona of trans modern Individual'(Pannosian, 2020, p. 2) or multinational human Being whom Benjamin R Barber in his "Citizens without Borders Glocal Civil Society and Confederalism", termed as the 'glocal citizen'(as cited in Pannosian, 2020, p.2). Nadia is the embodiment of the phenomenon of Glocalisation that enables her to transgress the interpersonal struggle of integration that features what Pannosian called 'acculturation versus traditionalism'(as cited in Pannosian, 2020, p.2). as Hamid opined that "identity is not a function of her religion nor ethnicity." This paper focuses on the figure of the refugee not only as an interrogation of national sovereignty but an embodiment of a newer kind of subjectivity, an embodiment of a 'new historical consciousness as Hannah Ardent puts it'. In that premise, Hannah Ardent impregnated the figure of the refugee with a 'new historical Consciousness' (as cited in Agamben, 1995, p. 1)

The two major sources of resistance to this project of the realizing or executing the Postnational imagination that Hamid addresses in his novel are the outward and the inward resistance. The former implies the exclusionary politics of the Northern countries adhering to the right-wing populism, where the denouncement of the refugees is often tried to be vindicated at the backdrop of the massive terrorist attacks by the Islamic militant groups. The emerging coterie of writers in Refugee fiction have vigorously undertaken the reexamination of the imperialist lenses through which the identity of all the asylum seekers in these northern countries are tried to be appropriated with that of terrorists. The latter form of resistance is faced by the migrant from within where one is confined by his own conservationist attitude, driven by a lingering instinct of preserving a part of his nostalgic self that inhibits his coalition with the culture of the host country.

This present paper shall consecutively analyze both outward and the inward forms of resistance flowed by the methods that Hamid embraces in his novel for obviating the obstructions that hinder the realization of the postnational future that the globe is heading towards. The paper shall endeavor to undertake an impartial diagnosis of the exclusionary strategies of the countries of the Global North in terms of their active as well as passive denunciation of the refugee population on one hand by considering the pragmatism of the threat by the different Islamic militant groups and on the other hand the plight of the asylum seekers whose survival is jeopardized in their home countries by these militant groups. Therefore, one needs to focus on the shared precarities of both the natives and the refugees for a holistic examination of the crisis.

\section{The outward form of Resistance: Precarity of the migrants}

Amid the multilayered crisis pertaining to the cultural, social, and ideological planes that an Asylum seeker encounters, the fundamental one is the resistance to their assimilation into the mainstream culture by the native population of the host nation, specifically of those communities 
hailing from the Muslim Countries. The resurgence of right-wing populism and the nationalistic agendas in Europe has further problematized the cultural integration of the refugees with the native population. Locating this resistant behavior within an Immunitary paradigm Robert Esposito note, "One can say that generally immunitas, to the degree, it protects the one who bears it from risky contact with those who lack it, restores its own borders that were jeopardized by the common" (as cited in Spencer, 2019, p.87). The native population makes all possible explicit and implicit efforts to resist contamination from the refugees.

In Hamid's novel, the vulnerability and the precariousness of the asylum seekers and the lifethreatening condition that they live in becoming prominent as paramilitary and civilian nativist mobs frequently attempt to check the further expansion of the migrants Saeed and Nadia encountered a massive "attack by a nativist mob when they sought asylum in London. Narrating the unmindful and terrible rage of this nativist mob, Hamid writes in the novel, "The mob looked to Nadia like a strange and violent tribe, intent on their destruction, some armed with iron bars or knives, and she and Saeed turned and ran, but could not escape."(2017, p.79). According to Cohen it is this "hostility and resentment [of] the indigenous population and the assimilated citizenry, ... [they develop] little bonding in the new setting. " (as cited in Hossain, 1997, p.4) Moreover a socio-cultural precariousness too features in the form of the spatial as well as the cultural demarcation between the natives and the refugee seekers, who lived in the 'light London' and the 'dark London'. As the number of refugees compounded with a great speed electricity supply to these migrant-occupied areas is cut. People in 'Dark London' where rubbish accrued, uncollected, and underground stations were sealed "wondered what life must be like in light London, where they imagined people dined in elegant restaurants and rode in shiny black cabs, or at least went to work in offices and shops and were free to journey about as they pleased." (Hamid, p.79) A constant sense of precarity haunts the refugees concerning the legitimacy of their residence as the deadline for their departure drew nearer, then nearer still, and then came and went, and they were still there, and the police had not charged, and they felt they had won some kind of a respite.(Hamid,p.79)

But a sudden halt in the nativist bombings ultimately hints towards the relaxation of the hegemonic powers. Meditating upon the possible reasons of the sudden withdrawal of the paramilitary forces Hamid notes in the novel:

Perhaps they had grasped that the doors could not be closed, and new doors would continue to open, and they had understood that the denial of coexistence would have required one party to cease to exist, and the extinguishing party too would have been transformed in the process, and too many native parents would not after have been able to look their children in the eye, to speak with head held high of what their generation had done.(Hamid, p.81) 
A separate section of the city has been dedicated to accommodating people coming from the other parts of the world which are called the 'London Halo'.

\section{Precarity of the Natives}

Alessandro Tiberio in his Impossible Landings: Precarity, Populism and Walling in a 'European' Refugee Crisis(2018) has remarked, "To achieve an impartial take on this issue of refugee assimilation, one needs to undertake "alternative readings of 'precarity', questioning exclusivists senses of belonging and based on appreciating relational forms of insecurity between differentlyprecarious 'European' and 'non-European' subjects, that may make a different politics of border renegotiation possible".(p.3) Acknowledging the viability of the threat to the social security of the natives on account of the inflow of the migrants Hamid in his interview with The Hinduarticulated "nativist sentiment is entirely understandable. But what we should be asking is, what actions do you take to enforce those feelings? (Ram, 2017)

Hamid in his novel meticulously juxtaposes the precarious state of the refuges with what may or may not be the subjectively designed or politically manufactured precarity of the indigenous people of the host countries. In Hamid's novel. The migrants are shown to be occupying:

unoccupied mansions in the borough of Kensington and similarly the great expanses of Hyde Parks, filling up with tents and rough shelters, such that it was now said that between Westminster and Hammersmith legal residents were in a minority, and native-born ones vanishingly few, with local newspapers referring to the area as the worst of the black holes in the fabric of the nation. (Hamid, p.70)

The trope of legality is instrumentalized on one hand to endanger the political status of the refugees and on the other hand to fabricate and intensify the fear of extermination of the natives. The natives fearing extermination by the migrants, how the politics of fear has been worked out The third and the last destination that Saeed and Nadia choose for seeking shelter in the city of Marin contains "almost no natives, these people having died out or been exterminated long ago......" (Hamid, p.108). Dwelling on the ambiguity around the notion of nativity in Marin, Hamid notes and I quote from the novel "And yet it was not quite true to say there were almost no natives, nativeness being a relative matter". (Hamid, p.108) Meditating upon the nostalgic loss of rootedness and loss of nativity of an old woman living in Marin Hamid writes:

every year someone was moving out and someone was moving in, and now all these doors from who knows where were opening, and all sorts of strange people were around, people who looked more at home than she was, even the homeless ones who spoke no English, more at home maybe because they were younger, and when she went out it seemed to her that she too had migrated, that everyone migrates, even if we stay in the same houses our whole lives because we can't help it. We are all migrants through time. (p.115) 


\section{Inward forms of Resistance.}

Adopting a holistic approach towards the proposal of the Postnational imagination, Hamid also considers the resistance that the refugee himself engenders hindering his amalgamation into multicultural form. This resistance and its antithetical counterpart are foregrounded through the dichotomic responses of the two lovers Saeed and Nadia to the abrupt displacement from their unnamed home country in the Global South due to the ongoing military tensions. According to Chambers, To some extent, Nadia aligns with generalizations about the global north and Saeed the global south' (2019, p.216). The dialectical juxtaposition of Saeed and Nadia is the most spectacular in the former's resistance to the integration in a foreign land and the latter's spontaneous amalgamation with the foreign multiculturalism.

After a rough experience living in the tents in Mykonos where Saeed and Nadia sought their first shelter as they escaped their war-torn city, they found themselves in a hotel room of some magnificent Mansion in London transported through one of the magic doors, only to discover people of myriad cultures and dialects delivered through one magical door of the mansion or the other. Saeed here emblematizes the inertia of rootedness that hampers his transition into a glocal citizen. As Pannosian notes he was "haunted by the dawning shade of othering"(2020, p.4). This becomes validated as Saeed keeps himself engaged in his tradition-bound practice of prayers, indulging with people of his native land thus insistent on inculcating the tradition ghettoization of people of his own community in the foreign land seeking vestiges of the previous life in their present circumstances, and remaining integrated with familial customs. Vijay Mishra observes this as a mode of compensating the "primal loss" (as cited in Hossain 2021, p.4)-the loss of one's psychic experience at home that one can never recuperate. This primal loss along with the memory of home gives rise to melancholia. As Hamid notes in the novel,

For Saeed existence in the house was more jarring. He was suspicious, especially of the other men around, of whom there were many, and he found it stressful to be packed in so tightly with people who spoke in tongues he did not understand." (p.69)

This tensional confrontation between Saeed's conservatism and Nadia's approach towards multiculturalism finds its accurate manifestation when expresses his intention of residing with people of their own country "Around a bend, on Vicarage Gate, was a house known to be a house of people from his country. Saeed began to spend more time there, drawn by the familiar languages and accents and the familiar smell of the cooking". When Nadia enquires the reason for this prospective spatial shift Hamid answers, "To be among our own kind" (Hamid, pp.82-83). As they were "from our country". Nadia sharp reply persuades Saeed and the readers to acknowledge the truth "From the country we used to be from" (Hamid, pp.82-83). Post National I9magination 89. In Saeed is embodied the collective fear of the community of what they regarded 
as 'cultural contamination' as put forward by Cordula Lemke in "Racism in Diaspora". (as cited in Hossain, 2021, p.3)

But contrary to this as Hamid foregrounded Nadia as the specimen of the glocal citizen in the novel. Nadia has assimilated the truth Nadia Butt has voiced in "Racism in Diaspora", "In a world of movement and mobility not 'purity' but 'impurity' in the cultural sphere is the order of the day. Nadia's evolving multiculturalism and cosmopolitanism becomes quite evident As Hamid put it in the following words in the novel:

"Nadia experienced the environment of the house as a bit like that of a university dormitory at the start of classes, with complete strangers living in close proximity, many of them on their best behavior, trying to add warmth to conversations and strike poses of friendship, hoping these gestures would become more natural over time. (p.72)

The house in which Saeed and Nadia took shelter is characterized by thus becomes a zone of cultural exchange with Nadia herself becoming a part of this intersectional network as she embraces this fact that "There were rough people in the house, but there were rough people everywhere, and in life, roughness had to be managed. Nadia thought it madness to expect anything else."(Hamid,2017, p.72) One of the prime exemplifications of this cultural networking is the meeting councils conducted primarily by the elder Nigerians with Nadia being the only young non-Nigerian among them. Despite the linguistic differences people in the group negotiated with each other through a slightly customized common language "that was built in large part from English, but not solely from English, and some of them were in any case more familiar with English than were others." (Hamid, p.73). In fact, they conversed in different variations of 'Englishes'. It is on account of this cultural and linguistic flexibility that Nadia could easily acclimatize herself with this evolving cosmopolitan community in the house.

\section{Technolozised Magic: The Magic Doors, a pathway to Postnational Future}

One of the prime tools that Hamid enterprised for his postnational project is the technologically customized Magic doors that thwarted the anthropogenic political divisions as the magic doors are 'discussed by world leaders as a major global crisis' (Hamid, p.83) as the operation of these doors are beyond regulation by any international regulatory body. It is Hamid's way of questioning the rigidity or the placidity of Traditional geopolitical borders which has already been anticipated in the novel in terms of globalized networking and transnational economics. Hamid's narrative design where the unlawful transmission of the refugees across borders following the economically feasible transmutation of information questions the legal complexities of cross border migration and thus his promotion of the propounding notion of a Postnational imagination.

Positioning the international refugee crisis in the backdrop of globalization Hamid frustrates the intolerant sensibilities of the global north that often promote and patronize the technologized 
transmission of information, a trade on which the western economy thrives but are reluctant on cross border movements of the refugees. The chapter entitled "patronize the artists of war" opens with a meditation on the role of "information" in the global system: We're all information, all of us, whether readers or writers, you or I." (Spencer, 2019, p.67) In an interview with NPR's Fresh Air, recounting for the reasons of introducing the magic doors Hamid admitted his intention on emphasizing the intensifying role of telecommunications advances in connecting people and mobilizing the economy.(as cited in Spencer, 2019, p.82)

Hamid tore apart the superficiality of the globalized world projecting the smooth functioning of the transnational economics in the first half of the novel which is in marked contrast with the legal, social, and cultural inhibitions that the refugees face in an attempt of resettlement in the Northern Nations. The ambiguity of these Northern Countries adhering to the ideologies of Right-Wing Populism is exposed as they could outsource services to the developing Nation of Global South But could not allow them or hesitated in allowing them the status of Legal citizens in their Nations. The Otherwise proponents of the globalized world become intolerant when the transmission of goods and services graduates to the movements of individuals belonging from other nationalities.

\section{Conclusion}

The exclusivity of Hamid's Novel lies in terms of the subtle optimistic resolution. If Hamid has employed the posthuman dimensions of the magic doors to render the anthropologically constituted national borders meaningless, then it has also been complemented with ceratin acts of humanity that envisioned the possibilities of a cosmopolitan world. It has been materialized as Hamid mentions the girl in Mykonos who befriended Nadia escorting them to a door leading them to London and the native boy in London rendering his humanitarian assistance in the face of the escalating tensions between the Natives and the migrants. Meditating upon the native boy's sensitivity and compassion towards the migrants Hamid elaborates about him as he is:

"just out of school, or perhaps in his final year, who came to their house and administered polio drops, to the children but also the adults, and while many were suspicious of vaccinations, and many more, including Saeed and Nadia, had already been vaccinated, there was such earnestness in the boy, such empathy and good intent, that though some argued, none had the heart to refuse him"(p.75)

Hamid's promotion of this postnational imagination in his fictive space is primarily driven towards persuading the state to adopt more liberalized, flexible, and humanitarian refugee policy norms. He insisted on generating a space for a glocalized world where nations would not only entertain to a purely economic transaction of goods and services but at the same time can become tolerant enough to allow the percolation of the rigid geopolitical borders, allowing a relaxation migration policy, and can arrest the politicization of the fear of the migrants among the indigenous 
population. His novel seeks for a commitment to share more equitably the burden and responsibility for hosting and supporting the world's refugees, protecting the human rights of all migrants, and countering xenophobia and intolerance directed towards migrants. Concerning the wider issue of South Asian identity or South Asia as a geopolitical space this particular paper tries to vandalize the complacent image of South Asia which has been continuously either bombarded from within and without. Even today when we have embarked on our journey to the third decade of the 21st century when all kinds of cultural, social, and geographical borders are being continuously thwarted by osmosis of information, both the nations of the global South as well as global north are anchored within our insistence for rootedness and borders. That these asylum seekers and refugees constitute an ambiguous section of a region of the halves of the globe, one needs to reconsider these undefined political spaces occupied by the refugees before boasting of a well-defined well bordered geopolitical entity.

Hamid's prime concern in the novel is to deliver the term refugee from its exclusivity of its sociopolitical context delivering it to a universal plane, as Hamid has reiterated in his interview with The Hindu, "but as I've got older, I've realized that the sense of feeling foreign is universal. "They" are not they; "they" are every one of us." Often he received criticism on account of his introduction of the Magic doors which according to many nullifies the practical hardships that the refugees encounter in their cross-cultural osmosis. Hamid has primarily implored his readers to acknowledge the truth of the Postnational future where movement is inevitable as Hamid has replied to The Hindu reverberates his anticipation of an optimistic future:

I think that the direction of history suggests that as a species we are moving towards greater equality and away from the notion that the accident of where you are born should fundamentally determine the course of your life. We should have a sense of optimism that the future is going to be better rather than nostalgia. The notion that we should somehow emulate the past is ridiculous - it wasn't glorious. (2017, Ram)

\section{Works Cited}

Agamben, G. (1995). "We Refugees". Symposium: A Quarterly Journal in Modern Literatures, Vol.49, No.2. pp.114-119.

Anderson, Benedict. (1983). Imagined Communities: Reflections on the Origin and Spread of Nationalism. Verso.

Arendt, H. "We Refugees". (2008). In J. Kohn \& R. H. Feldman (Eds.), The Jewish Writings, Schocken, pp. 264-274.

Bhabha, Homi K. (2004). The Location of Culture. Routledge.

Chambers, C. (2019). Making Sense of Contemporary British Muslim Novels. Palgrave Macmillan. 
11 Refugees from South Asian Islamic States at the footsteps of Global North: Reading Moshin Hamid's Exit West as an Anticipation of Postnational Future

Cohen, Robin. (1997). Global Diasporas: An Introduction. University of Washington Press.

Esposito, Roberto. (2008). Bios: Biopolitics and Philosophy. U of Minnesota P.

Frostrup, M., (Interviewer), \& Hamid, M., (Interviewee), 2017, March 4. Open Book [BBC Radio 4]. Retrieved from https://learningonscreen.ac.uk

Hamid, Mohsin. (2013) How to Get Filthy Rich in Rising Asia. Riverhead Books.

---. Exit West. (2017)Riverhead Books.

Hossain, Md. Alamgir. (2021) "Muslims in Diaspora: Negotiating Identity in Nadeem Aslam's Maps for Lost Lovers", South Asian Review, 42:1, , pp.94-108, DOI: 10.1080/02759527.2020.1772634.

Khattab, Nabil \& Mahmud, Hasan. (2019). "Migration in a turbulent time: perspectives from the global South, Migration and Development",8(1),1-6, DOI: 10.1080/21632324.2019.1552501

Krzyżanowski, Michał, Triandafyllidou, Anna \& Wodak, Ruth. (2008). "The Mediatization and the Politicization of the "Refugee Crisis" in Europe. Journal of Immigrant \& Refugee Studies," 16(2), 1-14. DOI: $10.1080 / 15562948.2017 .1353189$.

Lemke, Cordula. (2008). "Racism in the Diaspora: Nadeem Aslam's Maps for Lost Lovers." In Lars Eckstein, Barbara Korte, Eva Ulrike Pirker, and Christoph Reinfandt. (Ed).Multi-Ethnic Britain 2000p: New Perspectives in Literature, Film and the Arts, Rodopi, ( pp.171-186).

Mishra, Vijay. (2007). The Literature of the Indian Diaspora: Theorizing the Diasporic Imaginary. New York: Routledge.

Murshid, Navine. (2014). The Politics of Refugees in South Asia: Identity, Resistance, Manipulation, New York: Routledge.

Panossian, Vicky. (2020)."The metamorphosis: a literary analysis of the Arab Muslim refugee's interpersonal struggles of integration in London". British Journal of Middle Eastern Studies. DOI: 10.1080/13530194.2020.1758034.

Perfect, Michael. (2019). "Black holes in the fabric of the nation': refugees in Mohsin Hamid's Exit West", Journal for Cultural Research. 23(2), 187-201. DOI: 10.1080/14797585.2019.1665896

Said, Edward. (1997). Covering Islam: How the Media and the Experts Determine How We See the Rest of the World. Vintage Books.

Spencer, Matthew L. (2019) WITHOUT BORDERS: THE POSTNATIONAL IMAGINATION IN CONTEMPORARY ANGLOPHONE LITERATURE AND CULTURE. (Doctoral dissertation). Middle Tennessee State University. https://jewlscholar.mtsu.edu/handle/mtsu/6067

Tiberio, Alessandro. (2018). Impossible Landings: Precarity, Populism and Walling in a 'European' Refugee Crisis. (Doctoral Dissertation). University of California.

Vidya Ram. (2017) "That feeling of being a migrant is a universal one: Mohsin Hamid" Sept 27, 2017, HTTPS://WWW.THEHINDU.COM/OPINION/INTERVIEW/MOHSIN-HAMID-INTERVIEW-THAT-FEELINGOF-BEING-A-MIGRANT-IS-A-UNIVERSAL-ONE/ARTICLE19758108.ECE 